\title{
Introduction
}

\section{Views from the Shoreline: Community, Trade and Religion in Coastal Yorubaland and the Western Niger Delta}

\author{
Insa Nolte \\ University of Birmingham, UK \\ m.i.nolte@bham.ac.uk \\ Olukoya Ogen \\ Adeyemi College of Education Ondo, Nigeria \\ koyaogen@gmail.com
}

\begin{abstract}
This article provides an introduction to the Special Issue entitled, "Views from the Shoreline: Community, trade and religion in coastal Yorubaland and the Western Niger Delta." Introducing the 19 articles in this Special Issue, which cover the coastal stretch from Ikorodu (near Lagos) to Ore-Isi (Urhoboland) and Benin, the article maps out how the coast's lack of centralization, its complex settlement histories, and its underrepresentation in government and mainstream mission archives may be addressed by using multi-methods approaches and in-depth fieldwork. It emphasizes both the high mobility and heterogeneity of coastal communities and illustrates the diverse ways in which local leaders have mobilized a range of resources - including Islam, traditional practice, and especially Christianity - to ensure individual wellbeing and to affirm or re-shape local boundaries and hierarchies. This article argues that the study of the coast, like that of other borderlands, affirms that both mixing and the assertion of difference are constitutive of the political economy of the area.
\end{abstract}

\section{Introduction}

This Special Issue is an important step towards our long and jointly held ambition to re-think the history and historiography of the Yoruba from (one 
of) its margins. Given that neither colonial and postcolonial politics nor mainstream mission endeavors have focused on the Yoruba-speaking coast beyond Lagos and its environs, any study of coastal communities and trade must take account of multi-methods and bottom-up approaches. Yet such approaches reveal a degree of local mobility, exchange, and contestation that challenges the very notion of a cohesive and firmly bounded "Yorubaness," and suggests that the heterogeneous coastal stretch from the Lagos lagoon and the western Niger Delta constitutes both an important field of study in its own right, and illuminates the complexity of ethnogenesis both among the Yoruba and beyond.

Focusing on the largely, but by no means exclusively, Yoruba-speaking areas which are shaped by their proximity to the coastal waterways, the following articles explore how the lives of individuals and groups reflect the changing influence of economic opportunities and spiritual needs, both linked to and independent of political centers such as Lagos, cities in the Yoruba hinterland, and Benin. While many coastal settlements were part of larger kingdoms with upland capitals that could issue powerful commands, others were largely independent of these centers and so aligned themselves with separate economic and religious networks and strategies. As most settlements were constituted by different groups of immigrants, their diversity was an important asset, and local fortunes were often determined by the ability of different groups to leverage legal and sometimes illegal economic activities or the appeal of particular deities and religions to their advantage.

Yet within this highly mobile and competitive landscape, day-to-day wellbeing also relied strongly on local forms of collaboration. In many localities this is facilitated by a reckoning of descent both through matrilineal as well as patrilineal relations, providing individuals with larger extended family networks by making lineage and descent multilineal (cognatic). But networks of trade and other forms of collaboration - including temporary alliances for military or work purposes - also provided important linkages. Such networks were often sanctioned by, and part of, spiritual links; and local deities remained important for the local political economy even as Islam and Christianity, often established by migrants or itinerant preachers, attracted growing numbers of people and in some cases even became the focal points of community-making.

The study of the history, politics and culture of this under-researched stretch of the Nigerian coast makes a valuable contribution to the study of ethnic borderlands and boundaries, of decentralized African societies, and of local perspectives on larger historical developments. These range from the implicit references to the slave trade and the Portuguese presence in different ritual practices on the western Delta to the legal and not-quite-legal trading networks that continue to shape the local economy as well as specific local 
histories surrounding the achievements of great men - such as Prince Kosoko of Lagos and Epe and Balogun Jaiyesimi of Ikorodu - whose engagement with the colonial powers transformed the local political landscape.

Some of the articles in this Special Issue examine different forms of engagement between traditionalist, Muslim, and Christian groups. Studies of Iji Nla, Oju Ota, Ebibi, Malokun, and especially the deity of justice, Ayelala, emphasize the importance of the spiritual for establishing communal order and inter-communal peace. In addition to confirming the enduring appeal of traditional associations and deities, many articles in this Special Issue illustrate the importance of religion for economic and political organization. The spiritual and economic strategies of Muslim or Christian believers, and their ability to transform and re-found communities on the basis of exclusive religious practice, illustrate the importance of religion for economic success. The establishment of monoreligious Christian settlements, which are both unique in the Yoruba-speaking areas and often also include Yoruba-speakers who do not primarily indentify as Yoruba (but as Ijaw) deserve more detailed attention, first because they constitute an alternative to the multi-religious Yoruba communities of the hinterland and second because they illustrate the difficulties of transcending ethnic difference through religion.

Overall, the focus of this Special Issue on community, trade and religion provides a new starting point for the more systematic exploration of the Yoruba coast and its internal and external boundaries. As is apparent from the articles in this collection, the major Yoruba-speaking groups inhabiting this area are the Awori, Ijebu, Remo, Ikale and Ilaje, but the Ikale and Ilaje groups are also sometimes identified with Benin because they were once provinces of the latter. The important non-Yoruba groups along the coastal stretch include the Ijaw, Apoi, Egun, Urhobo and Edo, but also others - including non-Nigerians who settled in Nigeria as political migrants and refugees, traders, fisherfolk, and religious idealists. As several articles in this collection illustrate, most Yoruba-speaking settlements include groups of residents that identify with other groups, making it difficult to draw exclusive boundaries. These examples illustrate that both mixing and the assertion of difference are constitutive of the political economy of the area, and pose the question to what degree this applies to the Yoruba and non-Yoruba groups beyond the coast.

The following section offers a short overview of reasons for the general neglect of the area discussed in this issue. The next section examines how the processes that contribute to the coast's marginality in academic scholarship on the Yoruba and other coastal people also illuminate the factors that have dominated political and historiographical debates on the hinterland. While debates about (not) being Yoruba may be most visible in the coastal areas, they take place across the putative nation and illustrate the ongoing importance of as- 
serting difference and similarity in a range of local and regional debates. Following on from this, the article describes the wider context of research that led to the conference from which the articles for this Special Issue are drawn, and provides a short outlook discussing the included articles.

\section{Methodological challenges to the study of the Yoruba coast and the western Delta}

The lack of engagement with the coastal area between Lagos and the western Delta in historiographical debates about the Yoruba and other ethnic groups reflects a number of factors. Partly as an introduction to Toyin Falola's eloquent discussion of coastal Yorubaland in contemporary Yoruba Studies in this Special Issue, this section highlights how different political and intellectual projects and processes have contributed to the dearth of research on the Yoruba (and non-Yoruba) coast. It also illustrates how these lacunae have been addressed by the scholars whose articles are included in this issue, and, where appropriate, suggests how such approaches might be developed in the future by those wishing to populate the field.

Perhaps most importantly, local historiography has its roots in the late nineteenth-century interest of African missionaries and converts to Christianity in their own past. ${ }^{1}$ JDY Peel emphasizes that the work of local converts, and their engagement with the Bible, was crucial to the formation of ethnic identities. The translation of the Bible produced a "standard Yoruba" which created a commonality based on language between all those who spoke this language. Beyond that, the translated Bible texts themselves "promoted the idea that ethno-linguistic units were natural or God-given". ${ }^{2}$ But as pointed out above, the demarcation of the boundaries between ethno-linguistic units was often a complex process.

Following the publication of Samuel Johnson's seminal The History of the Yorubas in $1921,{ }^{3}$ most works on Yoruba history have focused on the Yoruba sub-groups that made up the old Oyo kingdom and those that participated in the nineteenth century Yoruba inter-state wars. ${ }^{4}$ At the same time, most stud-

1. J.D.Y. Peel, Religious Encounter and the Making of the Yoruba (Bloomington: Indiana University Press, 2000), 281.

2. J.D.Y. Peel, "Christianity and the Logic of Nationalist Assertion in Wole Soyinka's Isara", in David Maxwell and Ingrid Lawrie, eds., Christianity and the African Imagination (Leiden: Brill, 2002), 127-155.

3. Samuel Johnson, The History of the Yorubas: From the Earliest Times to the Beginning of the British Protectorate (1921; Norfolk: Lowe \& Brydone, 1976).

4. Samuel Johnson, The History of the Yorubas: From the Earliest Times to the Beginning of the British Protectorate (Lagos: CMS Bookshops, 1921). Johnson's failure to discuss east- 
ies of Benin have centered around the capital and its major towns, and their relations to other great powers. ${ }^{5} \mathrm{~A}$ more inclusive approach was pioneered by R.E. Bradbury, but his untimely death has meant that his work had less influence on Benin studies than it deserves. ${ }^{6}$ Thus the historiographical trends established during the early colonial period were a major factor for the neglect of this region by mainstream scholars. The alternative approach suggested by Ayodeji Olukoju in this issue, to consider the littoral as a "frontier" or border area to be studied in its own right and shaped both by exchange along the waterways and links to the hinterland, seems highly promising.

After the end of the colonial era, scholars of the post-independence Ibadan school of African History equated cultural respectability with a high level of political centralization. ${ }^{7}$ Consequently, apart from Lagos $^{8}$ and the upland parts of Remo ${ }^{9}$ and Ijebu, ${ }^{10}$ the history of coastal Yorubaland has largely been treated as a footnote to the history of Lagos, the Yoruba kingdoms of Ijebu or Ondo, or Benin. While coastal communities received some attention in de-

ern Yoruba-speaking communities such as the Ikale or Ilaje - not to speak of the Itsekiri as part of the imagined nation limits his vision of the Yoruba in particular ways. Johnson refers to the Mahin, an Ilaje subgroup, only in reference to a conflict over the control of the lagoon with Epe and describes them as "a piratical tribe" (465).

5. See, for example, Jacob Egharevba, A Short History of Benin (Ibadan: Ibadan University Press, 1960).

6. See R.E. Bradbury, The Benin Kingdom and the Edo-speaking Peoples of South-Western Nigeria (London: International African Institute, 1957). R.E. Bradbury carried out research on the oral history of smaller communities under Benin's influence but due to his untimely death in 1969, the findings were not published. His field notes are held in the Special Collections at the University of Birmingham, UK.

7. See, for example, Toyin Falola and Saheed Aderinto, Nigeria, Nationalism, and Writing History (Rochester: University of Rochester Press, 2010).

8. See, for example, Sandra Barnes, Patrons and Power: Creating a Political Community in Metropolitan Lagos (London: Manchester University Press for the International African Institute, 1986); Ade Adefuye, Babatunde Agiri and Akinjide Osuntokun, eds., History of the Peoples of Lagos State (Ikeja, Lagos, Nigeria: Lantern Books 1987); Kristin Mann, Slavery and the Birth of an African City: Lagos, 1760-1900 (Bloomington IN: Indiana University Press, 2010).

9. In addition to Insa Nolte, Obafemi Awolowo and the Making of Remo: The Local Politics of a Nigerian Nationalist (Edinburgh: Edinburgh University Press, 2009), see, Reverend D.O. Epega, Iwe Itan Ijebu ati Ilu Miran (1919; Ode Remo, Nigeria: Imole Oluwa Institute, 1934).

10. See Dr. B. O. Adebonojo, Itan Ido Ijebu (Ikeja, Lagos: John West Publications, 1990); E. A. Ayandele, The Ijebu of Yorubaland, 1850-1950: Politics, Economy and Society (Ibadan: Heinemann, 1992); Tunde Oduwobi, Ijebu under Colonial Rule, 1892-1960. An Administrative and Political Analysis (Apapa, Lagos: First Academic Publishers, 2004); O. O. Olubomehin, ed., The Ijebu of Western Nigeria. A Historical and Socio-Cultural Study, Ibadan: College Press and Publishers Ltd, 2001). 
bates about armed resistance to colonial rule, ${ }^{11}$ and their leaders sometimes featured in attempts to project Nigerian nationalism into the past ${ }^{12}$ studies of polities that included the coast tended to focus on the capitals associated with these conflicts. However, a focus on the centers of political power invariably emphasizes the agency of its rulers and people at the expense of the wider structures and practices that shape political consent and economic success beyond the center.

Many articles in this issue illustrate the insights that can arise from a focus on marginal communities. Adeyemi-Suenu's discussion of the 1865 defeat of the Egba challenges colonial sources on the conflict by arguing that only intricate alliances at the local level enabled Ikorodu to hold out until Lagos provided military support. Olubomehin's discussion of Ejinrin market in Ijebu documents how its rise and fall is linked both to the increase of local trade following the British annexation of Lagos in 1861, the bypassing of Ijebu by the railway, and the expansion of the road network after the First World War. Moving east, Mudasiru's study of Islam in Epe illustrates that the 1892 conquest of IjebuOde was a result of ongoing rivalry between Epe's Lagos and Ijebu citizens. In the twentieth century, the changing nature of traditional practice in Ikorodu, discussed by Balogun, illustrates both the growing influence of Lagos on its hinterland and the endurance of a particular local identity. But Lagosian influence along the lagoon was uneven: Ololajulo's contribution illustrates how the inability (or unwillingness) of the colonial state to enforce Christian norms regarding the treatment of twins contributed to the rise of Christian settlements in the 1940s. In Orimedu, Adewusi explains, remoteness from Lagos and indifference to the Nigerian expulsion of Ghanaian residents in the 1980s contributed to the growth and, in the long run, the prosperity of the settlement. Insights like these are often only recoverable through oral history methods and anthropological research.

In a related manner, anthropological research has frequently focused on culturally and politically cohesive groups, whose conceptual worlds and habitual practices could be discussed in a consistent manner. ${ }^{13}$ As a result, the coastal stretch from Lagos to the Western Delta has been partially included in ethnographies of the Yoruba and their coastal sub-groups, Benin and its "peo-

11. Cf. Michael Crowder, West African Resistance: The Military Response to Colonial Occupation (London: Hutchinson, 1971).

12. Kemi Rotimi and Olukoya Ogen, "Jaja and Nana in the Niger Delta region of Nigeria: proto-nationalists or emergent capitalists," Journal of Pan African Studies, 2.7 (2008): 48-59.

13. Frederik Barth, Ethnic Groups and Boundaries (Prospect Heights, IL: Waveland Press, 1998). 
ples," but also in studies focusing on the singular groups such as the Itsekiri, Urhobo, and Ijaw. But the treatment of this highly mobile area as a "cultural mosaic" means that practices associated with migration and exchange between groups are often ignored. ${ }^{14}$ Importantly, these exchanges are not always dominated by uneven relations between local centers and peripheries: in this issue, Adebua's discussion of the celebration of Ebibi festival in Epe shows that the community itself can be celebrated as the coming together of its different sections. In a very different vein, Ikuejube \& Funmilayo's discussion of environmental decline along the creeks of the Ugbo Ilaje highlights the continuities between Ilaje Yoruba-speakers and non-Yoruba-speakers in the oil-producing areas of the Western Delta.

The importance of trade across the coast's ethnic and language boundaries suggests that commodity histories and ethnographies may be illuminating. In this issue, Olupayimo's discussion of the illicit trade in home-brewed gin or Ogogoro points to the complex relationship between coastal trading networks and centralized or state authority. At the same time, Onipede's analysis of the expanding trade in fish along the lagoon illustrates both the shift from lagoon and creek to ocean fishing partly accelerated by oil spills, and the transformative power of government investment in a new road network. Similarly, the studies of the spread of Malokun worship to Mahin by Omojeje \& Adu-Peters, and the exploration of Ayelala's multiple myths of origin by Raheem \& Famiyesin, illustrate the importance of spiritual networks that transcend ethnic and group boundaries. Igboin's autobiographical reflection on Ayelala worship in Benin not only asserts the rationality of belief in this deity, but also illustrates the fears and needs that are behind the growing patronage of this deity. This suggests that, as in other decentralized areas of West Africa, the future study of commodities must include both the material and the spiritual. ${ }^{15}$

A final reason for the low volume of work on the coast to date may be the (relative) silence of the archives: the exclusion of many coastal polities from sustained missionary endeavor in the nineteenth-century, their political marginalization in the early colonial decades, and their distance from the road network for most of the twentieth century mean that missionary, colonial and even contemporary administrative documentation on many parts of coastal Yorubaland and the Western Delta is sparse and sometimes contradictory. As a result, as Afatakpa shows, the monotheist Igbe religion, whose Ore-Isi festival attracts worshippers from along the coast and beyond to a major festival in

14. Cf. Ulf Hannerz, "Culture between Center and Periphery: Toward a Macroanthropology, Ethnos, 54.3-4 (1989): 200-216.

15. Ute Röschenthaler, Purchasing Culture: The Dissemination of Associations in the Cross River Region of Cameroon and Nigeria (Trenton, NJ: Africa World Press, 2011). 
the Urhobo area of the Delta, has been long mis-recognized as a "traditional" religion.

Much missionary activity especially in Ikale and Ilaje was undertaken by small, non-conformist and local churches such as the Evangelist Band Mission led by E. M. Lijadu and the Zion and Holy Apostles communities. The fact that these have not been studied in detail reflects the slow engagement of scholarly literature with twentieth-century missionary activity by African-led missions, particularly beyond the revivals of the 1930s. Here too, the documentary evidence - where it is known to exist - is dispersed. Although some relevant documents are held in archives in Lagos and Ibadan, others remain in small private archives or tin-trunk collections in communities which were, until recently, most easily accessed by boat. ${ }^{16}$ Whether based largely on archival sources or on field-based interviews, Ayodokun's study of Lijadu's reliance on trade, Ololajulo's emphasis on the political economy of Zion and Apostolic settlements, and Adefi's elucidation of succession problems in both communities all illustrate the close relationship between Christian practice, social cohesion, and the adoption of local economic strategies.

Overall, then, the articles in this Special Issue both reflect and address the challenges of research on the coastal areas between Lagos and the western Delta. Taken together, their successful use of observation, interviews/oral history, and local historical genres provides convincing evidence for the need for a methodological shift towards an interdisciplinary approach. Following the insight that African borderlands are often defined by fractured bodies of knowledge, this Special Issue calls for an integration of disciplines in the humanities, social sciences, and beyond in order to give due recognition to the study of coastal Yorubaland and the western Delta.

\section{The Yoruba as a fluid and contested community}

The marginality of the coastal stretch illuminates the problematic nature of Yorubaness in a manner that has received no serious attention to date. Reflecting a general trend in the academic literature on ethnogenesis in African contexts to emphasize the processes that contributed to the main thrust or realization of identity formation, the history of the Yoruba has often been studied as a process of "becoming," which is associated with increasing internal homogeneity. This form of historiography may be the result of an implicit comparison of African ethnogenesis with European nation-building, which is often, albeit also not always correctly, understood as a unidirectional process culminating

16. Karin Barber, Africa's Hidden Histories: Everyday Literacy and Making the Self (Bloomington IN, Indiana University Press, 2006). 
in the emergence of clearly delineated national identities realized in nation-states. However, insofar as the ongoing struggles over identity and belonging along the coast are reflected in other parts of the Yoruba nation, they suggest that ethnogenesis is a far more complex process.

The Yoruba, as they understand themselves today, are a product of intellectual endeavors of the nineteenth and especially the twentieth century. But, like other modern nations, they were also imagined on the basis of pre-existing commonalities. And like elsewhere in the world, the boundaries produced by these older commonalities were put to use in overlapping but sometimes contrasting ways. But while political rivalries between Yoruba sub-groups have been explored in relation to different imaginations of the nation centred on Oyo or Ife, only the view from the margins illuminates the fluid nature of Yoruba ethnogenesis as a whole. The articles in this Special Issue provide the starting point for a reconsideration of the coastal areas not only as a neglected part of Yorubaland, but also as an important resource for re-thinking Yorubaness, and trajectories of ethnogenesis in Nigeria and African more generally.

The factors that shaped the imagination of the Yoruba as a cohesive group or nation included the extensive Ifá divination corpus, ${ }^{17}$ shared language, and shared historical experience. But these factors produced very different forms of belonging. Thus, the Ifá divination corpus, which explains the shared origin of many settlements in the area through their descent from the mythical "first" town of Ife (usually identified as the Yoruba town of Ile-Ife), is shared by communities stretching from present-day southern Ghana to eastern Nigeria and includes the whole coastal area up to Benin. ${ }^{18}$ In contrast, the influence of the Oyo Empire, which was originally identified with the ethnonym Yoruba, and the shared experience of war and migration following Oyo's collapse, which features centrally in the Johnson's History of the Yorubas, only affected the coastal areas east of Lagos in a marginal way. The ambiguous positions of the communities that might be considered Yoruba on the basis of some (but not all) commonalities - such as many of those among the coast - suggest that ethnogenesis among the Yoruba, and perhaps in Nigeria and Africa more generally, remains an ongoing and contested project.

As suggested by JDY Peel, the spread of standard Yoruba through Christian missions, the modern school system, print, and other media were instrumen-

17. Ifá, sometimes also known as Afá, was carried to Cuba, Trinidad and Brazil by enslaved diviners from all these areas.

18. Insa Nolte, "Spirit: Histories of Religion and the Word," in Gus Casely-Hayford, Janet Topp Fargion and Marion Wallace, eds., West Africa: Cultures of the Word (London: British Library, 2015), 48-71. 
tal to a closer identification of many Yoruba speakers with the Yoruba nation. ${ }^{19}$ Indeed, the adoption of the Yoruba language and some Yoruba institutions by the Apoi, and the increasing use of Yoruba among the Arogbo - both historically non-Yoruba migrant groups of Ijaw origin inhabiting territory originally settled by Ikale and Ilaje - illustrate that Yoruba linguistic proficiency and residence can be an important marker of identity even among non-Yorubas. ${ }^{20} \mathrm{But}$ at the same time, growing numbers of Ogu or Egun speakers living west of Lagos in the coastal areas of Badagry and its hinterland, who are historically considered to speak a dialect of Yoruba, assert that what they speak constitutes a separate language. Given the early presence of Christianity and the historically high literacy in this area, their claim complicates the notion that the shared encounter with Christianity, and the joint participation in Yoruba print and literary culture produced an enduring "imagined community". ${ }^{21}$ The complicated relationship between language and identification reflected in these contrasting processes clearly shows that ethnic identity is not reducible to one factor.

Groups have also sought - either sporadically or more consistently - to mobilize alternative forms of origin or belonging to those associated with the centrality of Yorubaness or Ile-Ife. In the 1990s, Ekiti leaders pragmatically emphasized the difference of Ekiti identity from other Yoruba-speakers in order to lay the foundations for their own federal state. ${ }^{22}$ Less clearly linked to local ambitions is the longstanding claim of many Ijebu leaders that the population of their ancient kingdom originates from Wadai or the Sudan, which challenges the centrality of Ile-Ife to twentieth-century Yoruba identity. ${ }^{23}$ More recent claims from Ode Ugbo in Ilaje, asserting that it is home to the original settlers of mythical Ife, potentially destabilize existing Yoruba (and Benin) hierarchies and reverberate with subaltern histories elsewhere in southern and eastern Yorubaland that challenge the link between mythical Ife and present-day Ile-Ife. ${ }^{24}$

19. However, English (and Pidgin) also played an important, complex, and so far, neglected role in this process.

20. Neither of these groups claims to be Yoruba, but they also clearly differentiate themselves from other Ijaw.

21. Benedict Anderson, Imagined Communities: Reflections on the Origin and Spread of Nationalism (London: Verso, 1983).

22. Brennan Kraxberger, "Negotiations of 'Tradition' in Nigeria: Creation of States, the Military and Local Domains", Journal of Asian and African Studies, 44 (2009): 449-67.

23. See, for example, "Ijebus Are From Sudan, Awujale Insists," PM News, 25 June 2010.

24. See Olukoya Ogen, "History, Politics and Ethnicity: A Critique of the Existing Canons of Yoruba Historiography," First Professor S.O. Arifalo Memorial Lecture, Adekunle Ajasin University, Akungba-Akoko, 12 November 2014, 19-32. 
Finally, while the coastal stretch has a stronger Christian and traditionalist presence than some parts of Yorubaland, its religious diversity is typical for Yorubaland as a whole. Throughout the Yoruba-speaking areas, historic rivalries have found expression in the competitive conversion to Islam and Christianity, and communities with a dominant religion that differed from that of the Yoruba political elite have sometimes resisted the pull of their mobilization. From the 1960s to the 1980s, the leadership of the Christian Obafemi Awolowo was most strongly opposed in the predominantly Muslim parts of Oyo. ${ }^{25}$ In contrast, the prominent roles of Muslims Moshood Abiola in the 1990s and, more recently, Bola Tinubu, have had to contend with a lack of support from the predominantly Christian areas of Ondo and Ekiti. While intra-regional opposition was seldom phrased in terms of religion, and although all leaders retained strong support in some parts of Yorubaland dominated by the "other" religion, these constellations illustrate that Muslim and Christian dominated visions of the nation do not always coincide.

Taking this idea further, we suggest that the coast's apparent religious peculiarity, namely the emergence of explicitly Christian settlements, also illuminates processes in other parts of Yorubaland. Thus, the town of Ilorin attracted a multi-ethnic group of Muslim settlers after it gained independence from Oyo. Eventually internal ethnic rivalry was subsumed under an Islamic identity, and after Ilorin joined the jihād of the Sokoto Caliphate in the nineteenth century, it was instrumental to Oyo's decline and collapse. Ilorin's Islamic identity has meant that it is often excluded from both popular and academic debates of Yorubaness. ${ }^{26}$ This is misleading for many reasons (including its posthoc nature), but what concerns us here is that this exclusion reifies the traditional and implicitly mixed-religious structures of authority adopted in most Yoruba towns. As the Zion and Holy Apostles towns along the Ilaje coast illustrate, in the context of weak central authority, the principles of Yoruba communal organization were open to appropriation by both Muslims and Christians. Clearly a serious engagement with Yoruba history and practice must take into account the potential of such creative adaptability.

Overall, then, we suggest that our study of coastal Yorubaland and its non-Yoruba neighbors challenges the reification of the Yoruba nation as "complete," and draws attention to the diverse and ongoing processes that continue to shape and define it. Like the term "coastal Yorubaland," the Yoruba nation itself is an ongoing and uncompleted political project that has both inspired

25. J. D. Y. Peel, "The Cultural Work of Yoruba Ethnogenesis," in E. Tonkin, M. McDonald, \& M. Chapman, eds., History and Ethnicity, (London: Routledge, 1989).

26. Cf. J.D.Y. Peel, Christianity, Islam and Orisha Religion: Three Traditions in Comparison and Interaction (Oakland CA: University of California Press, 2016), 12. 
leaders and created (sometimes temporary) malcontents and opponents. And like in the coastal stretch we examine, debates on Yorubaness draw on diverse, competing and yet mutually implicated discourses centered on language, politics, religion, history, and mythology that suggest that this nation cannot be reduced to a static community with fixed external boundaries: its real significance is that it remains full of potentialities.

\section{The History of this Special Issue}

This Special Issue arises from a European Research Council (ERC) Starting Researcher Grant for a project focusing on the reasons for the relatively peaceful coexistence of Islam, Christianity and traditional practice in the Yoruba-speaking parts of Nigeria and entitled "Knowing each other: Everyday religious encounters, social identities and tolerance in southwest Nigeria." Led and co-ordinated by Insa Nolte and Olukoya Ogen respectively, the project was based at the University of Birmingham, UK, and Osun State University, Nigeria (UNIOSUN) between 2012 and 2017. The experience of leading the "Knowing each other" (KEO) research team in two countries and on two continents, and with colleagues from a range of disciplinary perspectives, has transformed us, and we are grateful for the insights and friendships we have gained as a result.

Our research for the KEO project has covered Ekiti, Kwara, Lagos, Ogun, Ondo, Osun, and Oyo States, where we have carried out the first large-scale survey on religious identification in Nigeria's Yoruba-speaking states. ${ }^{27}$ Following on from this project, we have investigated how the existence of religious difference, and in particular the practices associated with peaceful religious coexistence, are linked to different social identities. Following on from a period of research in Ede, one of southwest Nigeria's most strongly Muslim towns, we produced an edited book that focuses on religious coexistence beyond the paradigm of toleration. ${ }^{28}$ Based on research across the southwest of Nigeria, we continue to explore how religious difference is mobilized by men and women, members of extended families, and across generations.

Our interest in the multiple ways in which groups and individuals put religion to use also led us to the Yoruba-speaking coast, where high mobility and

27. Insa Nolte with Rebecca Jones, Khadijeh Taiyari and Giovanni Occhiali, "Exploring Survey Data for Historical and Anthropological Research: Muslim-Christian Relations in Southwest Nigeria," African Affairs, 115.460 (2016): 541-561.

28. Insa Nolte and Olukoya Ogen, "Beyond Religious Tolerance: Muslims, Christians and Traditionalists in a Yoruba Town," in Nolte, Ogen and Rebecca Jones, eds., Beyond Religious Tolerance: Muslims, Christians and Traditionalists in an African Town (Rochester, NY: James Currey Publishers/Boydell and Brewer, 2017), 1-30. 
low degree of political centralization mean that religion plays a particularly important, and yet little examined, role in the organization of trade and communal belonging. Our interest in the coastal areas also arose from the desire to explore the many similarities and links between Ijebu-Remo ${ }^{29}$ and Ikale, ${ }^{30}$ our respective areas of research. The lower degrees of centralization, and the complex histories of settlement we observed in these areas stand in some contrast to the more hierarchical models generally associated with Yoruba polities, but are also more typical - though not exclusively so - for many of the southern and eastern Yoruba-speaking parts of southwest Nigeria.

In early 2016 we advertised a call for papers for a conference on "Community, trade, and religion in coastal Yorubaland," which was held at Adeyemi College of Education, Ondo, on 6-8 December 2016. However, the abstracts we received convinced us that in the highly mobile communities situated along the waterways between Lagos and the western Delta it would be limiting - if not impossible - to focus exclusively on Yoruba communities. The discussions that arose in and around the conference confirmed to us that Yorubaness, like other identities, continues to be negotiated both with regard to the more centralized hinterland and in the engagement with other language and ethnic groups.

Like the KEO project as a whole, the articles in this Special Issue rely strongly on historical and anthropological methodologies, but they also employ approaches rooted in religious studies, philosophy, political science, and linguistics. Multidisciplinary approaches are able to take account of locally rooted case studies that offer a bottom-up viewpoint that can both complement and sometimes challenge European and colonial perspectives conserved in archival documents. In addition to different disciplinary approaches, these proceedings bring together articles written from different personal and religious perspectives, exploring communities based on Muslim, Christian and traditionalist practice.

Both editors were committed to ensuring that all articles had a clear focus and argument. While we acknowledge the patience and hard work of all contributors, we are particularly grateful to Jide Ololajulo, whose comments on all articles relating to the Ilaje area have helped to avoid mistakes in geography and nomenclature. Given the difficulties of fieldwork, the scarcity of archival material, and the tendency of the facts produced in this manner to present themselves with all their contradictions, this required a high degree of collab-

29. See Nolte, Obafemi Awolowo and the Making of Remo.

30. See Olukoya Ogen, "The Ikale of South-Eastern Yorubaland, 1500-1900: A Study in Ethnic Identity and Traditional Economy," unpublished Ph.D. Thesis, Department of History and Strategic Studies, University of Lagos, Akoka, Lagos, 2006. 
oration between editors and contributors. Reflecting the intense engagement of editors, other members of the conference, and fellow contributors, we are convinced that the articles in this Special Issue include both new empirical material and original arguments.

While the conference associated with these proceedings has attracted some outstanding and well-established scholars of Nigerian history, culture, and religion, we also invited the Nigerian members of our research team to contribute to it. Charles Omotayo, Adebayo Adewusi, Oluwafunminiyi Raheem, Mike Famiyesin, and Joseph Ayodokun worked as members of the KEO team in different capacities. Many of them carried out archival research or fieldwork on coastal communities as part of their brief, and were thus eminently qualified to be part of the conference.

Beyond that, all of the team members in this Special Issue completed their Masters Degrees while working with our project and have begun, or are looking to begin, $\mathrm{PhDs}$. We consider the opportunity to produce a research article of publishable quality in this Special Issue as a further preparation for their academic careers. We thank them for their idealism, commitment and enthusiasm, and we are proud to have been their mentors. We hope they will be part of an academic future where their contributions to the study of the Yoruba coast and the western Delta will be recognized.

\section{Outlook}

Contributions to the Special Issue are included largely in the order of their presentation at the conference, loosely moving from general reflections to a geographical focus starting in Ikorodu in the western lagoon and moving eastwards to the Ijaw, Benin, and Urhobo-speaking areas of the Delta. This means that the article by our keynote speaker, Toyin Falola, and by our first lead speaker, Ayodeji Olukoju, both of which consider the Yoruba-speaking coast more generally, follow this introduction. We are grateful to both of them for drawing together the strands of current scholarship on the coastal areas, and for thinking about the ways in which that scholarship might move forward in the future.

Following on from these general considerations, articles by Adeyemi-Sueno, Balogun, and Omotayo discuss the history and (modern) traditions of Ikorodu and Ijede, located just north-east of Lagos. They are followed by an exemplary study of Ejinrin market in the context of a shifting economy of the lagoon's waterways by Oladipo Olubomehin, our second lead speaker, which sets out the virtues of detailed local historical research. From Ejinrin, the focus of the Special Issue moves to the divided community of Epe, discussed by $\mathrm{Mu}$ - 
darisu and Adebua respectively, and - across the lagoon - Orimedu, whose local fishing economy is explored by Adewusi.

The articles by Onipede and Olupayimo then move eastwards to explore the trade in fish and illicitly brewed spirits from Ilaje or Delta areas, while Ikuejube \& Funmilayo discuss the impact of the oil industry on the traditional Ilaje economy and environment. Omojeje \& Adu-Peters and Raheem \& Famiyesin investigate the ongoing importance of the coastal deities Malokun and Ayelala for economic success and moral cohesion respectively, while Ayodokun focuses on the early spread of Christianity in Ikale and Ilaje through the trading activities of the Evangelist Band Mission.

The new political economies associated with Christianity are investigated in Ololajulo's analysis of the political economy of coastal Zion and Holy Apostles Christian communities, and in Adefi's comparative discussion of leadership and succession in the Evangelist Band Mission and the Zion/ Apostles towns. Igboin's examination of the spread of Ayelala practice in Benin illuminates ongoing debates about the deity's power as well as the personal concerns it is able to address. Afatakpa's study of Igbe religion, popular among Urhobo migrants along the coast and the centre of a large annual festival in Urhoboland, illustrates yet another aspect of the relationship between community, trade and religion in the Western Delta.

We hope that these articles will not only stimulate further debates but also encourage other researchers, institutions of higher education and research funders to invest time and resources into research on coastal Yorubaland and the Delta. We believe that any scholarly efforts at publication must be accompanied by teaching, and the designing of a curriculum for courses relating to the peoples and cultures of coastal Yorubaland and the Delta would be an important step towards dissemination. It is also important to produce a large body of relevant resources through the documentation of multidisciplinary fieldwork, the archiving of findings, the execution of surveys and other forms of data collection, and digitization. In the absence of contemporary archives, it would be a step in the right direction to set up a central collection of relevant documents, field materials and publications to be preserved and made available to interested researchers.

Finally, during the conference, our discussions revealed the shared experience of working on an area marked by significant infrastructural and developmental neglect. All conference contributors, whether native to the coastal strip or not, were moved by the resilience of the people that they had encountered during their research. Following several debates about the difficulties faced by both people in this area and the researchers themselves, Toyin Falola's call to produce a communiqué as part of the conference was taken up enthusiastical- 
ly. The resulting text was agreed by all participants and published in the Nigerian Guardian on 23 February 2017. It is also enclosed in this Special Issue. 